Erin Matariki Carr

\title{
Stemming the Flow of Corporate Human Rights Abuses: Incorporating the Ruggie Report in the Common Law Doctrine of Foreign Judgment Enforcement
}

Submitted for the LLB (Honours) Degree

Faculty of Law

Victoria University of Wellington

2013 


\begin{abstract}
The eminent case of Aguinda v Chevron Corporation, currently in its twentieth year of litigation, represents a growing phenomenon in international commercial litigation between multinational corporations and victims of human rights abuse from developing nations. In 2011 Aguinda awarded approximately US\$18 billion against Chevron for extreme environmental and human rights abuse from oil contamination in the Amazon region of Ecuador. Chevron has removed its assets from Ecuador's jurisdiction leaving the plaintiffs without remedy.

This paper traces Aguinda to Canada where the plaintiffs' action in Yaiguaje to enforce the judgment to satisfy their debt is stayed. This paper critiques this decision of the Ontario Superior Court of Justice as being unprincipled and failing to consider the wider implications of its decision on the struggle for developing nations to remedy human rights abuses by multinational corporations.

This paper argues that the common law doctrine of foreign judgment enforcement must evolve to reflect the needs of modern society. The paper does this by incorporating the "Protect, Respect and Remedy: A Framework for Business and Human Rights" report released by the United Nations in 2011.
\end{abstract}

\title{
Key words:
}

Doctrine of foreign judgment enforcement

Human rights

\section{Table of Cases:}

Aguinda v Texaco, Inc., 303 F.3d 470, 480 (2d Cir. 2002).

Maria Aguinda y Otros vx. ChevronTexaco Coporation, Corte Superior de Justicia, Nuevo Loja, Ecuador, Jucio No. 002-2003 (Mar. 16, 2006); Maria Aguinda Salazar et al. v ChevronTexaco Corp., No. 002-2003 (Super. Ct. of Nueva Loja May 7, 2003) (Ecuador).

Yaiguaje et al v Chevron Corporation (2013) ONSC 2527, CV-12-9808-00CL. 


\section{Introduction}

Earlier this year the Superior Court of Justice in Ontario stayed a motion to enforce Aguinda $v$ Chevron Corporation (Aguinda), an Ecuadorean judgment now in its twentieth year of litigation. 'Aguinda, which has been described as the 'world's largest environmental lawsuit', represents a growing phenomenon in international commercial litigation where plaintiffs from developing countries bring claims against large multinational corporations operating in their territories for breaching human rights or environmental standards. This case and its current struggle for enforcement is a symbol of the failure of international law to provide effective legal mechanisms to hold multinational corporations accountable for their actions abroad, especially in developing countries which are more vulnerable due to less stringent government regulation over social rights. ${ }^{2}$

In 2011 Aguinda awarded the Ecuadoreans approximately US\$18 billion against Chevron for oil contamination over great areas in the Amazonic region of Ecuador which devastated the environment and the health of the indigenous habitants of the area. ${ }^{3}$ Having received judgment in Ecuador, the plaintiffs in Aguinda now rely on the doctrine of foreign judgment enforcement to have any access to remedy as Chevron's assets have been removed from Ecuador's jurisdiction.

The Ecuadoreans have since taken their case to be enforced in Canada where the motion was stayed. ${ }^{4}$ In making its decision to stay the motion, the Court took an unprincipled approach to the law, ultimately basing their verdict on practical matters and consequently failing to determine the case on its merits. The Court also failed to respect the fundamental common law doctrines of comity and obligation. More importantly, however, are the wider policy implications of this decision that were not considered by the Court. Specifically, the impact this decision will have on the growing number of cases of human rights and environmental standards abuse occurring in the developing world against multinational corporations arguably operating "with impunity" abroad. ${ }^{5}$

\footnotetext{
${ }^{1}$ Simon Romero \& Clifford Krauss, A Well of Resentment, N. Y. Times, May 15 2009, at B1.

${ }^{2}$ Erin Foley Smith "Right to Remedies and the Inconvenience of Forum non Convenienes: Opening US Courts to Victims of Corporate Human Rights Abuses" (2011) 44 Colum JL \& Soc Probs 145 at 15.

${ }^{3}$ Maria Aguinda y Otros vx. ChevronTexaco Coporation, Corte Superior de Justicia, Nuevo Loja, Ecuador, Jucio No. 002-2003 (Mar. 16, 2006); Maria Aguinda Salazar et al. v ChevronTexaco Corp., No. 002-2003 (Super. Ct. of Nueva Loja May 7, 2003) (Ecuador) [Aguinda]. ${ }_{5}^{4}$ Yaiguaje et al v Chevron Corporation (2013) ONSC 2527, CV-12-9808-00CL [Yaiguaje].
} 
This paper considers these wider implications in light of the recent report "Protect, Respect and Remedy: A Framework for Business and Human Rights" by the Special Representative of the Secretary-General, John Ruggie (the Ruggie Report), released by the United Nations in 2011. ${ }^{6}$ The Ruggie Report identifies the growing global need to "[adapt] the human rights regime to provide more effective protection to individuals and communities against corporate related human rights harm." ${ }^{7}$ The report is implemented through a framework of General Principles that rests on three core pillars; the State duty to protect human rights abused by third parties, the corporate responsibility to respect human rights, and the need for more effective access to remedies. ${ }^{8}$

It is argued that the common law doctrine of foreign judgment enforcement can be used as one effective tool by States reflect the Ruggie Report and protect human rights by holding multinational corporations accountable for their actions abroad in cases of human rights and environmental abuse.

This paper is divided into three parts. Part I will outline the Ecuadorean case of Aguinda to provide context for its latest challenge, the Canadian decision to stay the motion of enforcement of the judgment. This Part will then critique the Canadian decision on the basis that the Court took an unprincipled approach to the law, and failed to respect the doctrine of international comity. Part II outlines the Ruggie Report and uses it to critique the Canadian decision. The wider implications of the Canadian decision are discussed in the context of the current challenge of the relationship between globalisation, human rights and multinational corporations. This Part then considers how the common law doctrine of foreign judgment enforcement may be expanded to reflect the aims of the Ruggie Report and respond to the challenge of balancing the relationship between human rights and globalisation of business. Part III concludes this paper by considering how the courts may apply the doctrine of foreign judgment enforcement to Aguinda in light of the Ruggie Report.

\section{Part I}

\section{A Aguinda: An Illustration of a Global Human Rights Dilemma}

\footnotetext{
${ }^{6}$ John Ruggie "Report of the Special Representative of the Secretary-General on the issue of human rights and transnational corporations and other business enterprises" A/HRC/17/31 (2011) [Ruggie 2011].

${ }^{7}$ John Ruggie "Report of the Special Representative of the Secretary-General on the Issue of Human Rights and Transnational Corporations and Other Business Enterprises: Protect, Respect and remedy: A Framework for Business and Human Rights, delivered to the Human Rights Council" UN Doc A/HR/8/5 (Apr 7 2008) at 189 [Ruggie 2008].

${ }^{8}$ Ibid.
} 
The plaintiffs in Aguinda are a group of indigenous citizens originating from various tribes in the North-East of the Ecuadorian Amazon (the Oriente). The defendant, Chevron Corporation (who inherited the litigation from the original defendant Texaco Inc after their acquisition of the company in 2001), is a multi-national oil exploration and extraction company based in the United States of America. The plaintiffs claimed against Chevron for extreme environmental and personal injuries arising out of Texaco's oil extraction operations in the Oriente from 1964 to 1992, namely the spilling of billions of gallons of oil throughout the area which seriously impaired - and continues to impair - the health of the local inhabitants. ${ }^{9}$

The procedural history of Aguinda can be summarised into three main stages: the initial proceedings in the United States dismissed for forum non conveniens; the re-filing of the case in Ecuador where the trial and judgment were held; and the current international proceedings with the Ecuadoreans seeking to enforce their claim and Chevron seeking to have the judgment set aside.

The Ecuadoreans filed their initial claim against Chevron in 1993 in New York. Instead of defending the action, Chevron chose to bring a claim of forum non conveniens arguing that the trial should be held in the alternative forum of Ecuador as it is "available, adequate and more appropriate than the US court for adjudicating the suit." ${ }^{10}$ Forum non conveniens is a doctrine that ultimately aims to provide access to justice by having the case heard in the most convenient forum available without placing any 'undue burden' on either of the litigants or the court. ${ }^{11}$ In United States jurisprudence, the location where the abuses allegedly occurred is often chosen over the United States as it is seen as more convenient and provides visible

\footnotetext{
9 Aguinda v Texaco, Inc., 303 F.3d 470, 480 (2d Cir. 2002) [Aguinda 2002]; Lucien J. Dhooge Aguinda $v$ ChevronTexaco: Mandatory Grounds for the Non-Recognition of Foreign Judgments for Environmental Injury in the United States 19 J. Transnat'l L. Pol'y 1 2009-2010 at page 6: "Oil production and pipeline operations were alleged to have resulted in the discharge of twenty-sex million gallons of crude oil and toxic wastewater into the surrounding environment. Approximately 2.5 million acres were impacted by oil-related discharges into wetlands, streams and rivers and leeching into soil and groundwater as well as by combustion of crude oil and flaring of natural gas... the consumption of contaminated water and livestock, inhalation of polluted air and exposure to hydrocarbons in the soil were alleged to have severely affected the health and life expectancy of residents."

${ }^{10}$ Whytlock page 1447

${ }^{11}$ Whytlock page 1454; Rosemary H. Do "Not Here, Not There, Not Anywhere: Rethinking the Enforceability of Foreign Judgments with Respect to the Restatement (Third) of Foreign Relations and the Uniform MoneyJudgments Recognition Act of 1962 in Light of Nicaragua's DBCP Litigation" (2007-2008) 14 Sw. J. L. \& Trade Ame. 409 at 412 (noting: Historically, a dismissal for forum non conveniens resulted in a significantly smaller settlement or, in some cases, the abandonment of the entire lawsuit because foreign plaintiffs, especially those from developing countries, were unwilling or unable to re-file the case in their home countries where the multinational often held significant economic power or where the judiciaries were corrupt.); see also: Sasha Lilley "Barren Justice" (2004) CorpWatch <http://corpwatch.org/article.php?id=11330>.
} 
justice for the society abused. ${ }^{12}$ Forum non conveniens is a common tactic used by multinational corporations in foreign commercial litigation as the United States is perceived to be typically more "pro-plaintiff" than the foreign country due to the more developed tort law. ${ }^{13}$ The foreign country is also often preferred as the corporation often exercises considerable influential economic power over governments that court foreign investment. ${ }^{14}$ Chevron's argument was upheld and the New York court dismissed the claim for forum non conveniens in 2002 on the condition that Chevron submitted itself to the jurisdiction of Ecuador and abode by any judgments made there. ${ }^{15}$

In 2003 the plaintiffs re-filed their claim in Ecuador. After an eight year trial the Provisional Court of Sucumbios found Chevron liable for approximately \$US18 billion in damages in February 2011. Chevron unsuccessfully appealed this decision which was upheld by the Ecuadorean appellate court. ${ }^{16}$

This case has since become an international issue as the Ecuadoreans are determined to have their judgment enforced and Chevron is determined for it to be dropped, claiming the trial was a fraud. ${ }^{17}$ Chevron has removed all of its major assets from Ecuador making it impossible for the plaintiffs to enforce the judgment in their home country. ${ }^{18}$ The Ecuadoreans now seek to enforce the judgment in as many jurisdictions as it takes to collect the entirety of the damages awarded. ${ }^{19}$ Chevron refuses to pay the judgment debt, claiming the trial was conducted fraudulently and has since sued individual lawyers involved for fraud and racketeering and actively sought to have the case dismissed both in the United States and on the international stage. ${ }^{20}$

\footnotetext{
${ }^{12}$ Whytlock page 1454, Aguinda case 2002.

${ }^{13}$ Whytolock page 1447 (find quote re the different torts can use in the US that are not prevalent in other jurisdictions).

${ }^{14}$ Whytlock page 1446 and friends

${ }_{15}$ Aguinda, above $\mathrm{n} 9$.

${ }^{16}$ Aguinda above n 3.

${ }^{17}$ Wall Street Journal article

18 Steven R. Donzinger "Rainforest Cherbonyl: Litigating Indigenous Rights and the Environment in Latin America" (2004) Hum. Rts. Brief.

${ }^{19}$ Suraj Patel "Delayed Justice: A Case Study of Texaco and the Republic of Ecuador's Operations, Harms and Possible Redress in the Ecuadorian Amazon" (2012) 26 Tul. Envtl. L. J. 71.

${ }^{20}$ Julian G Ku and George T. Conway "When corporate defendants go on offense; how an \$18 billion judgment against Chevron in Ecuador turned into a battle royal with a top US law firm" in Wall Street Journal (online), July 4, 2013, http://search.proquest.com/docview/1389531582?accountid=14782: Since the judgment was awarded to the Ecuadorean plaintiffs Chevron has initiated an international arbitration against Ecuador at the Permanent Court of Arbitration in the Hague under the US-Ecuador bilateral investment treaty, launched a civil racketeering lawsuit in federal court against the plaintiff's chief US lawyer, Steven Donzinger, his Ecuadorean
} 
The procedural history of Aguinda is not unique. ${ }^{21}$ With the contemporary advent of globalisation, multinational corporations have spread with increasing ease throughout the developing world. This has led to an increase in lawsuits against multinational corporations by alleged victims of human rights abuse accusing multinationals of taking shortcuts with regards to labour rights, health and safety rights and environmental standards among others. ${ }^{22}$ Add to this the popularity of forum non conveniens as a means to 'forum shop' out of the United States and the subsequent adoption of 'plaintiff-favouring' qualities of the US tort law jurisprudence by the judiciaries and legislatures in developing countries. ${ }^{23}$ Where a judgment is awarded against the multinational corporation it is often not enforceable because of the small value, or entire lack of, the corporations' assets within the jurisdiction. ${ }^{24}$ This results in growing numbers of judgments seeking to be enforced around the world. Common law jurisdictions are unique in that they have the capacity to enforce a judgment from any country rather than only judgments from countries with enforcement treaties, as in most civil law jurisdictions. This makes common law jurisdictions more attractive for judgments from

counsel and their expert consultants, Stratus. The top US law firm Patton Boggs later sued Chevron after it was accused of fraud of their part.

${ }^{21}$ Whytlock pages 1447-1450; Examples of other cases with similar procedural histories include In re Union Carbide Corp. Gas Plant Disaster, 634 F. Supp. 842, 844 (S. D. N. Y. 1986), aff'd, 809 F.2d 195 (2d Cir. 1987) (The infamous Bhopal disaster in India where the Union Carbide of India Ltd leaked dealy methyl isocyanate gas over a Bhopal suburb killing thousands in 1984. Dismissed from the US courts for forum non conveniens); Dow Chemical Co. v Alfaro, 786 S. W. 2d 674 (1990) (Thousands of banana workers became sterile because of exposure to the pesiticide dibromochloropropane or DBCP which was manufactured in the United States by the Shell Oil and Dow Chemical corporations. This case had some success in the United States although ultimately the final settlement was trivial); Wiwa v Royal Dutch Petroleum Co., 226 F.3d 88 (2d Cir. 2000) (Initially dismissed for forum non conveniens but decision overturned by the Second Circuit. Upon facing trail in the United States, the defendants settled the case with the plaintiffs for a significant sum).

${ }^{22}$ Dante Figueroa "Conflicts of Jurisdiction Between the United States and Latin America in the Context of Forum Non Conveniens Dismissals" Vol 37 Miami Inter-American Law Review 199 (2005-2006) (noting "Globalisation means more trade, easier communications, faster means of transportation, increased international commerce and also more litigation for U.S. companies conducting business overseas.")

${ }^{23}$ Whytlock pages 1447-1450; Dante Figueroa "Conflicts of Jurisdiction Between the United States and Latin America in the Context of Forum Non Conveniens Dismissals" Vol 37 Miami Inter-American Law Review 199 (2005-2006) (listing anti-forum non conveniens retaliatory legislation: Law of Defense of Procedural Rights of Citizens and Residents 1997 (Costa Rica), Law of Defence of Procedural Rights of Nationals and Residents of Guatemala 1997 (Guatemala), the Special Law to Process Lawsuits Filed by People Affected by the Use of Pesticides Manufactured with DBCP 2000 (Nicaragua)); Walter W. Heiser "Forum Non Conveniens and Retaliatory Legislation: The Impact on the Available Alternative Forum Inquiry and on the Desirability of Forum Non Conveniens as a Defence Tactic" Vol 56 Kansas Law Review 609 - 662 (2009); William E. Thomson \& Perlette Michele Jura "Unconstitutional Judgments for Import: Constitutional Limitations on Recognition and Enforcement of Abusive Foreign Judgments" Vol 43 Pepperdine Law Review Online 43-64 (2011);

${ }^{24}$ Examples: Dow Chemical Co. v Alfaro, above n 21; In re Union Carbide Corp. Gas Plant Disaster, above $\mathrm{n}$ 21. 
developing countries that tend not to have enforcement treaties with more developed countries. $^{25}$

To date, the Ecuadoreans have filed enforcement actions in Canada, Colombia, Brazil and Argentina. The jurisdictions of Colombia, Brazil and Argentina are subject to the InterAmerican Convention on Extraterritorial Validity of Foreign Judgments and Arbitral Awards and the Inter-American Convention on the Execution of Preventative Measures; these are essentially reciprocal enforcement treaties with Ecuador that fall outside of the scope of this paper. ${ }^{26}$ Canada has stayed the action against enforcement of their judgment. ${ }^{27}$

\section{B Yaiguaje: The Canadian Decision}

In May 2012 the Ecuadoreans commenced the action in Yaiguaje v Chevron Corporation to enforce their judgment in the Superior Court of Justice in Ontario, Canada. ${ }^{28}$ The action was brought against Chevron Corporation and its Canadian subsidiary, Chevron Canada Limited. ${ }^{29}$ The action was stayed by the Court on 3 May $2013 .{ }^{30}$

\section{$1 \quad$ The doctrine of foreign judgment enforcement at common law}

Before considering the Court's decision in Yaiguaje, it is necessary to understand the functions of the doctrine of foreign judgment enforcement at common law.

Foreign judgments have been enforced through the common law for over three hundred years. ${ }^{31}$ Historically the common law considered itself bound to enforce foreign judgments on the basis of international comity. ${ }^{32}$ This theory has evolved into the current theory for enforcement and recognition at common law, the doctrine of obligation. An often cited

\footnotetext{
${ }^{25}$ Albert Venn Dicey, Lawrence Collins and J. H. C. Morris Dicey, Morris and Collins on the Conflict of Laws, above $\mathrm{n} 22$, at 636 [Dicey].

${ }^{26}$ Inter-American Convention on Extraterritorial Validity of Foreign Judgments; Arbitral Awards and the InterAmerican Convention on the Execution of Preventative Measures.

${ }^{27}$ Yaiguaje, above n 4 at [111].

${ }^{28}$ Ibid at [13].

${ }^{29}$ Ibid at [15]; Note that the original action also included Chevron Finance Canada Limited, but that was discontinued in August 2012.

${ }^{30}$ Ibid at [111].

${ }^{31}$ Goddard and McLachlan page 57, [5.1]

${ }^{32}$ Goddard 57; Dicey 666.
} 
definition of this doctrine is that of the House of Lords decision in Schibsby $v$ Westenholz in $1870:^{33}$

The judgment of a court of competent jurisdiction over the defendant imposes a duty or obligation on him to pay the sum for which judgment is given, which the courts in this country are bound to enforce.

Foreign judgments are not directly enforceable as the sovereignty of states necessarily prevents the imposition of one state's laws into a foreign jurisdiction. ${ }^{34}$ However, the growing inter-connectedness of states requires that the law enable foreign judgments to be enforced extraterritorially. ${ }^{35}$ The doctrine of foreign judgment enforcement balances these interests by enforcing all judgments that satisfy certain criteria and do not offend the sense of justice of the enforcing court.

Primarily, parties seeking to enforce a foreign judgment must bring an action to the receiving court under a specific treaty, legislation or at common law. ${ }^{36}$ If successful, the foreign judgment will be enforced in the receiving jurisdiction just as a local judgment would. ${ }^{37}$ As Ecuador does not have any specific treaties with either of the jurisdictions considered in this paper (Canada, New Zealand, the United Kingdom or Australia) nor fall under any relevant legislation, the action to enforce Aguinda must be brought at common law.

The criteria between the different common law jurisdictions differ slightly, however all derive their foundations from English common law. A judgment of a foreign court is enforceable at common law where it is a final and conclusive money-judgment (other than for the payment of taxes or other penalties) and the receiving court recognises that the foreign court is of "competent jurisdiction" or had the jurisdiction to give the judgment seeking to be enforced. ${ }^{38}$ Once these criteria are satisfied, the judgment is prima facie enforceable in the receiving jurisdiction, subject to the limited defences of fraud, denial of natural justice or that the enforcement of the judgment would be contrary to public policy. ${ }^{39}$

\footnotetext{
${ }^{33}$ Schibsby v Westenholz (1870) LR 6 QB 155; see also Joel R. Paul "The Transformation of International Comity" 71 Law \& Contemp. Probs 192008.

${ }^{34}$ Goddard and McLachlan page 57; Dicey, above n 25 at 666; Spiro article "this is the true meaning of the phrase... extra territorium jus dicenti impune non paretur" which translates to "one who exercises jurisdiction out of his territory cannot be obeyed with impunity", page 60

${ }^{35}$ Spiro article, page 60; Ralf Michaels article, page 2, http://scholarship.law.duke.edu/cgi/viewcontent.cgi?article=2699\&context=faculty scholarship

${ }^{36}$ Goddard and McLachland page 57, Dicey 666.

${ }^{37}$ Goddard, 57

${ }^{38}$ Dicey, above n 25 at r 35; Schibsby v Westenholz

${ }^{39}$ Dicey, above n 25 at 616-619.
} 
A judgment may be deemed final and conclusive even where it is subject to appeal, an appeal is pending, or where it is a default judgment liable to be set aside by the court that pronounced it. ${ }^{40}$ However, if the judgment is liable to be abrogated or varied by the court that rendered it, it will not be treated as final and conclusive. ${ }^{41}$ The requirement for the judgment to be final and conclusive precludes the judgment debtor from attacking it in the receiving court on the grounds that it is incorrect in fact or law. ${ }^{42}$ The judgment is considered res judicata and shall be enforced as it stands in the receiving jurisdiction. ${ }^{43}$ The judgment must be a money-judgment for a debt, a definite sum of money or a sum that is easily calculable. ${ }^{44}$

The criteria to determine whether the foreign court was of competent jurisdiction differ slightly between the distinct common law jurisdictions. Essentially, however, the receiving court must be satisfied that the foreign court had jurisdiction over the defendant for the judgment to be enforceable. ${ }^{45}$ This will be granted where the judgment debtor was either present in the jurisdiction at the initiation of the proceedings, claimed or counterclaimed in the proceedings or, in some way voluntarily submitted to the jurisdiction of the court. ${ }^{46}$ In Canada, a foreign court will also be recognised as having jurisdiction where they have a "real and substantial" connection with the subject matter. ${ }^{47}$

Thus, subject to the limited defences outlined above, a receiving court at common law is bound to enforce a judgment upon a judgment debtor within their jurisdiction to fulfil their obligation to pay their debt.

(a) Arguments of the parties

In the proceedings before the Canadian court the plaintiffs argued that they had a final and conclusive judgment for a definite debt. ${ }^{48}$ The foreign court had recognisable jurisdiction to give the judgment seeking to be enforced as, not only did it have the "real and substantial

\footnotetext{
${ }^{40}$ Ibid at $577-578$.

41 Ibid.

${ }^{42}$ Carl Zeiss Stiftung v Rayner \& Keeler Lts (No 2) [1967] 1 AC 853.

${ }^{43}$ Borm Reid 58

${ }^{44}$ Beatty v Beatty [1924] 1KB 807 (CA).

${ }^{45}$ Spiro article, page 60.

${ }^{46}$ Dicey, above $\mathrm{n} 25$ at 588-599.

${ }^{47}$ Beals v Saldanha [2003] S.C.J. No. 77 at [210].

${ }^{48}$ Yaiguaje, above n 4 at [9].
} 
connection" with the subject matter, but the defendant had voluntarily submitted to the jurisdiction of the foreign court. ${ }^{49}$ The plaintiffs argued that the judgment was thus prima facie enforceable. Furthermore, by virtue of the foreign judgment being enforceable, the Canadian court had the jurisdiction to enforce it. ${ }^{50}$

Instead of raising a defence to the plaintiffs' argument Chevron argued that the Ontario Court should stay the action on the basis that it did not have jurisdiction to enforce the Ecuadorean judgment and that the assets the plaintiffs claimed in Canada were not Chevron's at all, but belonged to the separate legal entity Chevron Canada. ${ }^{51}$ Thus, even where the Court did have jurisdiction, Chevron argued that this "academic exercise" of determining whether the judgment was enforceable in Canada amounted to nothing but a drain on judicial resources as the corporate veil prevented the Court from ultimately being able to provide a practical remedy. ${ }^{52}$

\section{(b) Reasoning of the Court}

Brown $\mathrm{J}$ held that the Court did have jurisdiction to recognise and enforce the Ecuadorean judgment. His Honour further agreed with the plaintiffs that the evidence showed the judgment satisfied the criteria of being a final and conclusive money-judgment that was rendered by a competent court. ${ }^{53}$ Thus, the judge agreed that the Ecuadorean judgment was prima facie enforceable at common law.

Despite those findings, the judge stayed the motion on the basis that even if the judgment was ultimately enforced there would be no practical benefit for the plaintiffs. As Chevron was adamant to defend the action "until Hell freezes over", His Honour found that continuing the proceedings would only serve to consume significant judicial resources. ${ }^{54}$ The Court held that: ${ }^{55}$...a stay of this action is justified in light of the very unique facts presented by this case... Any recognition of the Ecuadorian Judgment by this Court would have no practical effect whatsoever in light of the absence of exigible assets of the judgment debtor in this jurisdiction... the evidence disclosed that a bitter, protracted and expensive

\footnotetext{
${ }^{49}$ Yaiguaje, above n 4 at [6].

${ }^{50}$ Ibid at [26].

${ }^{51}$ Ibid at [13] and [15].

${ }^{52}$ Ibid at [88].

${ }^{53}$ Ibid at [77]-[81].

${ }^{54}$ Ibid at [110]-[111].

${ }^{55}$ Ibid at [111].
} 
recognition fight would ensue consuming significant time and judicial resources of this Court... Ontario courts should be reluctant to dedicate their resources to disputes where, in dollar and cents terms, there is nothing to fight over.

The Court found that Chevron Canada was a "7th generation indirectly-owned subsidiary" whose shares were owned by another separate legal entity named Chevron Canada Capital Company. ${ }^{56}$ In light of this, it was found that Chevron did not beneficially own Chevron Canada's assets and the plaintiffs had "no success in their assertion that the corporate veil of Chevron Canada should be pierced... so that its assets become exigible to satisfy a Judgment against its ultimate parent." 57

The Court reasoned that the stay could be lifted should the plaintiffs provide new evidence that Chevron does indeed possess, or is likely to shortly possess, assets in the jurisdiction. ${ }^{58}$ Until then, however "...the parties should take their fight elsewhere to some jurisdiction where any ultimate recognition of the Ecuadorian Judgment will have a practical effect."59

\section{$3 \quad$ Critiques}

It is important for judges to take practical considerations into account when making any decision. At common law there are no legal obligations on the receiving court to enforce a foreign judgment. ${ }^{60}$ Thus it is understandable that, where a receiving court stands to donate a significant amount of its time and resources to an enforcement action that ultimately will not bear any final product for the judgment creditor, it might exercise its right to stay the action.

However a number of critiques can be made of the Canadian judgment. Firstly, the court's approach in this case was unprincipled because it only served the practical needs of the judiciary and abandoned the needs of the parties and wider community to have the legal issues addressed. The judge's reasoning suggests there are new barriers for foreign plaintiffs to overcome before having access to a remedy that is arguably already owed to them, given the foreign judgment. Secondly, it fails to respect the ever evolving doctrine of comity between nations and leaves the law uncertain in an area of private international law that requires clarity. These two critiques are considered in greater detail below. A third critique of

\footnotetext{
${ }^{56}$ Yaiguaje, above n 4 at [91]-[93].

${ }^{57}$ Ibid at [109].

${ }^{58}$ Ibid at [112].

${ }^{59}$ Ibid at [111].

${ }^{60}$ Ralf Michaels, page 3 "in absence of treaty commitments, countries are under no obligation to recognize and/ enforce foreign judgments. Although nearly all countries now do so regularly, this state practise is not considered specific enough to create actual rules of customary international law."
} 
the judgment is considered in Part II. There it is observed that the Canadian court failed to take into account the wider implications of their decision, namely how it affects the growing problem of corporate human rights abuse in our globalised world.

(a) An unprincipled approach to the law

Whether the judgment creditor can claim assets in the receiving jurisdiction is irrelevant to the legal question of whether their judgment should be enforced or not. The fact that there are no assets available to satisfy the debt only serves to make the jurisdiction less attractive for a plaintiff to initiate an action, but it does not detract from the principle that a judgment that has satisfied the prescribed criteria should be enforced. The judgment creditors may decide that the action is no longer worthy of pursuit, but the court should not make this decision. This is strongly reiterated by Peppal $\mathrm{J}$ in BNP Paribas (Canada) v Méc: $:^{61}$

In my view... the existence of assets of the judgment debtors in Ontario is irrelevant to the question of whether the court should grant recognition to the Quebec judgment. The plaintiff has the right to satisfy itself whether the defendants have or will have assets in Ontario and, if so, to seize them. If it is unsuccessful in this regard, it simply will be in the same position as other judgment creditors.

This is particularly true when the foreign judgment concerns human rights abuse as it then also holds a symbolic value that alone is worthy of recognition and enforcement by the court. This is a growing occurrence in the United States where many foreign plaintiffs are beginning to bring actions under the Alien Tort Claims Act. It has been observed that: ${ }^{62}$

Often the defendants in these cases are not within the United States, and have few US assets. There is therefore little prospect that plaintiffs will collect damages against these individuals. Nevertheless, ATCA cases are symbolic, representing a judicial pronouncement on wrongs inflicted on the victims of some of the world's worst human rights abusers.

A court must strive to adjudicate the matter on principle after considering the validity of any arguable defence. Chevron's assurance to prolong the litigation "until Hell freezes over and then fight it out on the ice" does not justify refusing to continue the action and simply avoid the legal issues. Brown $\mathrm{J}$ acknowledged this, stating that his decision to stay the motion does not mean that "a court should acquiesce in the face of rhetorical sabre-rattling by a defendant.

\footnotetext{
${ }^{61}$ BNP Paribas (Canada) v Mécs (2002) 60 OR (3d) 205 at [13]. Note that the same law of recognition and enforcement of foreign judgments applies between judgments from different regions of Canada as to foreign countries.

62 Alien Tort Claims Act 1789 (codified in 28 U.S.C. § 1350); John H. Currie, Craig Forcese, Valerie Oosterveld "International Law: Doctrine, Practice, and Theory" Toronto, Ontario, Irwin Law Inc 2007, page 684.
} 
Far from it." ${ }^{63}$ His Honour justified the decision on the basis that the case is "very unusual" and has a long history. ${ }^{64}$ Bearing in mind that the Aguinda is already prima facie enforceable and the judge has not be filed Chevron's defences, this is an especially unconvincing justification.

Furthermore, as explained in above, Aguinda is not unique. Similar cases are becoming more frequent with the rise of economic globalisation. ${ }^{65}$ In light of this, the only effect of the Court's decision has here is to encourage judgment debtors to adopt an aggressive technique of litigation, raise another barrier to enforcement and, consequently, to a remedy for the judgment creditor.

(b) Failure to comply with the doctrines of comity and the doctrine of obligation

The doctrines of comity and obligation form part of the underlying principles of private international law and aim to foster relations and cooperation between sovereign states. The definitions of these doctrines evolve as society becomes more global and inter-dependant and consequently requires more cooperation between nations. ${ }^{66}$ It is now widely accepted that complying with comity is less a matter of "mere courtesy and good will"67 and more a matter of obligation upon states. ${ }^{68}$

In staying the action the Court also failed to comply with the doctrines of comity and obligation. While there is no legal obligation binding states to abide by these doctrines, the refusal to comply requires serious consideration and justification due to the history and practical rationales behind the existence of the doctrines. As Peppal $\mathrm{J}$ held in BNP Paribas, "the purpose of comity is to secure the ends of justice... the court should grant its assistance in enforcing an outstanding judgment, not raise barriers." ${ }^{\prime 69}$ This paper argues that practical considerations are not an appropriate legal basis to defeat a plaintiff's right to have a decision enforced in a foreign jurisdiction.

\footnotetext{
${ }^{63}$ Yaiguaje, above n 4 at [111].

${ }^{64}$ Ibid.

${ }^{65}$ See Part II below.

${ }^{66}$ Joel R. Paul "transformation of comity" article

${ }^{67}$ Hilton v Guyott cited in Ralf Michaels article; See also Paul article, page 20.

${ }^{68}$ Joel R. Paul "transformation of comity" article

${ }^{69}$ BNP Paribas (Canada) v Mécs, above n 61 at [12]; see also Morguard Investments Ltd. v. De Savoye, 1990 CanLII 29 (SCC), [1990] 3 S.C.R. 1077, 76 D.L.R. (4th) 256.
} 
The practical rationales behind the doctrine have, however, remained much the same. By enforcing foreign judgments courts promote certainty in the law between states and avoid contradictory decisions and re-litigating issues that have been decided abroad. ${ }^{70}$ It is in the general public interest that there is an end to litigation and no repetition of the same issue. ${ }^{71}$ Furthermore, it is in the interests of states to harmonise and encourage international transactions. ${ }^{72}$ The growing importance placed on harmonising this area of the law is illustrated by the increasing number of bilateral and multilateral conventions such as global enforcement conventions, regional instruments and conventions on specific substantive subjects. $^{73}$

The threat that Chevron will prolong litigation demonstrates the urgency to allow the plaintiffs to proceed to the next step in this action and bring an end to the litigation, whether that is to ultimately enforce the judgment or reject it based on a defence raised by Chevron. The Court's recommendation that the plaintiffs re-file their action in a jurisdiction where any ultimate enforcement of their judgment will have practical effect, such as the United States, also promotes the continuance of the litigation. The Court's decision to stay the action promotes the continuance of litigation and is thus contradictory to the principles of comity.

\section{Part II}

A distinctive feature of the decision in Yaiguaje is the lack of consideration given to the human rights of the local indigenous community. This is particularly significant given the 2011 Ruggie Report, which found that States, and thus the courts, are to be responsible for protecting against human rights abuse by third parties. This Part argues that the State, when determining whether to enforce a foreign judgment, has a duty to consider the promotion and protection of human rights by corporations and other third parties.

Instead, the Canadian court's decision sets a poor standard for other common law jurisdictions when faced with a request of enforcement from similar controversial cases involving human rights. The Court's decision permits future courts to reject cases like Aguinda to prioritise their judicial resources. This in turn encourages multinational

\footnotetext{
${ }^{70}$ Ralf Michaels [A]

${ }^{71}$ Borm Reid page 54

${ }^{72}$ Ralf Michaels [A]: "interest reipublicae ut sit finis litium" and "nemo debet bis vexari pro eadem causa,"

${ }^{73}$ Ralf Michaels, [C]. Examples include the Hague Convention on Foreign Judgments in Civil and Commercial Matters, signed 1 February 1971
} 
corporations to follow Chevron's aggressive litigation technique to ultimately avoid any liability.

A Wider Implications of Yaiguaje

$1 \quad$ Context of globalisation: The growing imbalance between business and human rights

The age of globalisation has brought with it the rise of multinational corporations, spreading themselves throughout the developing world. Their investment, which is usually seen as crucial for the economies of these developing countries, has come at the cost of poor regulation of human rights and environmental standards. ${ }^{74}$ International law has not kept up with this phenomenon and there are no legally binding procedures in place to hold multinational corporations accountable for their actions abroad. ${ }^{75}$

Multinational corporations are becoming increasingly more powerful, with a number of the larger multinational corporations earning superior incomes than the GDPs of several small to medium sized countries. ${ }^{76}$ Of the world's top 150 economic entities in $2012,58 \%$ is made up by corporations. ${ }^{77}$ In more tangible terms, Royal Dutch Shell generated revenues that surpassed the GDPs of 171 countries in $2012^{78}$ and United States based multinational, WalMart, is now the world's third-largest employer exceeded only by the militaries of the United States and China. ${ }^{79}$ Consequently, many daily business decisions of large multinational corporations have a much more direct and significant impacts on societies around the world than most sovereign governments do. ${ }^{80}$ In their book Global Reach: The Powers of Multinational Corporations Barnet and Muller note that multinational corporations' decisions impacted: ${ }^{81}$

\footnotetext{
${ }^{74}$ Foley Smith article

${ }^{75}$ Foley smith

${ }^{76}$ Lippmann

77 Global Trends "Corporate Clout 2013: Time for Responsible Capitalism" https://www.globaltrends.com/reports/?doc id=500539\&task=view details

78 Global Trends "Corporate Clout 2013: Time for Responsible Capitalism" https://www.globaltrends.com/reports/?doc_id=500539\&task=view_details

${ }^{79}$ Christopher Albin-Lackey, Jan 2013, "Without Rules: A Faile $\overline{\bar{A}}$ Approach to Corporate Accountability" in Human Rights Watch http://www.globalpolicy.org/social-and-economic-policy/international-trade-anddevelopment-1-57/transnational-corporations/52255-without-rules-a-failed-approach-to-corporateaccountability.html?itemid $=\mathrm{id} \# 47070$

${ }^{80}$ Lippman; Global Policy Forum - Albin-Lackey; Ruggie Report

${ }^{81}$ Barnet and Muller, cited in Lippman
} 
where people live; what work, if any, they will do; what they will eat, drink and wear; what sorts of knowledge schools and universities will encourage; and what kind or society their children will inherit.

However, there are no legally enforceable mechanisms in place to ensure multinational corporations make their decisions with these societies at heart. It seems illogical that when a citizen has a complaint against a government agency, they may seek recourse at a regional, national and international level ${ }^{82}$ while multinational corporations and other corporate entities address human rights practises with legally unenforceable voluntary initiatives and selfcreated policies. ${ }^{83}$ The 2005 report of the United Nations High Commissioner on Human Rights identified over 200 initiatives to align business with human rights including international instruments such as treaties, nationally based standards such as constitutions and legislation, certification schemes, voluntary initiatives and social and environmental indices amongst other smaller schemes. ${ }^{84}$ Of these initiatives, only the national legislation and constitutions are legally binding on companies along with any contractual agreements a company may have with commercial partners. ${ }^{85}$ Accordingly, the obligation to hold corporations accountable falls to states which must provide access to remedies for victims of corporate human rights and environmental abuses. ${ }^{86}$ However, this obligation proves difficult to uphold for both home and host states given the economic power and, consequently, the heavy influence of multinational corporations. ${ }^{87}$

Furthermore, multinational corporations exercise a strong influence over host states, especially in developing countries. It is less expensive for multinational corporations to operate in countries where there is little regulation around social and environmental standards. ${ }^{88}$ This provides a strong incentive for multinational corporations, when looking to invest, to encourage less stringent regulations in their negotiations with states. ${ }^{89}$ This is particularly true, and therefore more problematic, for developing countries than for countries

\footnotetext{
${ }^{82}$ Foley-Smith, page 150 and 156 - regional human rights court and UN treaty bodies can only hear complaints against states, not private actors. For example the Rome Statute creating the International Criminal Court has the authority to try states and individuals but not corporations.

${ }^{83}$ Ruggie 2011, above n 6; Albin-Lackey

${ }^{84}$ United Nations High Commissioner on Human Rights on the responsibilities of transnational corporations and related business enterprises with regard to human rights at [7]

${ }^{85}$ Ibid at [9].

${ }^{86}$ Ruggie 2011, above n 6; Foley Smith

87 'Home state' refers to the country where the corporation is based; 'host state' refers to the country where the corporation operates and usually from where the legal proceedings emanate.

${ }^{88}$ Foley Smith page 151

${ }^{89}$ Ibid.
} 
already in the OECD. ${ }^{90}$ Developing countries compete for investment from multinational corporations by offering less regulation and binding bilateral investment treaties often with strong clauses preventing the state from making unilateral changes to social and environmental standards. ${ }^{91}$ This means that even where a host state later wants to impose more stringent regulations to protect human rights and the environment, they face binding international arbitration that could result in a heavy penalty for breaching the relevant treaty. $^{92}$

The case of Aguinda offers a clear example of this. When oil was found in the Oriente in 1967, it was declared a "salvation of Ecuador's economy" which would finally "pull the nation out of chronic poverty and "underdevelopment"." with Texaco Inc it had: ${ }^{94}$

practically no environmental regulations, no technical knowledge of oil operations, no scientific or public-health expertise, no governmental oversight capabilities - and no clue that it even needed such things. It needed money, pure and simple.

Thus despite the fact that Chevron claims to have followed all necessary Ecuadorean laws while it operated in the Oriente, it was of little effect as their law did not protect the human rights of the indigenous inhabitants, or the surrounding environment. ${ }^{95}$

Multinational corporations also have a heavy influence over their home states. ${ }^{96}$ All countries have some laws requiring corporations to uphold at least basic human rights and

\footnotetext{
${ }^{90}$ Ruggie 2008, above n 7 at 196: noting “A study conducted jointly for this mandate and the International Finance Corporation shows that contracts signed with non-OECD countries constrain the host State's regulatory powers significantly more than those signed with OECD countries".

${ }^{91}$ Foley Smith, 151; E.E. Daschbach "Where there is a will there is a way: the cause for a cure and remedial prescriptions for Forum non conveniens as applied in Latin American Plaintiff's Actions against US multinationals" 13 L. \& Bus. Rev. Am. 11, 24 (2007).

92 This is worse for extraction corporations which have operations lasting for over half a century or more; Ruggie 2008, above $\mathrm{n} 7$ at 196: These clauses ensure that any alteration made by the state that detrimentally affected the MNC investment could be taken to an international arbitration tribunal and are treated strictly as commercial disputes with little, if any, regard to public interest factors including human rights.

93 Judith Kimberlin "Oil, contact and conservation in the Amazon: Indigenous Huaroni, Chevron and Yasuni" 24 Colo. J. Int'l Envtl. L. \& Pol'y 43 (2013) at page 2.

${ }^{94}$ William Langewiesche "Jungle Law" in Vanity Fair, May 2007 http://www.vanityfair.com/politics/features/2007/05/texaco200705.

95 Foley Smith page 151

${ }^{96}$ Foley-Smith page 157; Deva, Surya "Regulating Corporate Human Rights Violations: Humanizing Business" 2012 published by Routledge in New York, page 50 .
} 
environmental standards, in their own territories and abroad. ${ }^{97}$ The challenge, however, lies in putting these laws into practise. Many home countries of the world's biggest multinational corporations, including the United States, European nations and other countries such as Brazil and China, have failed at managing their corporations' operations abroad. ${ }^{98}$

The reluctance of governments to interfere with their corporations is based on a fear that requiring more stringent standards would place their business at a competitive disadvantage in comparison to corporations from other countries. ${ }^{99}$ Home governments also fear that the corporations may relocate their headquarters to another state with less regulation, thereby removing many benefits from the home state's society such as taxes and employment, among other factors. ${ }^{100}$ Another reason is that multinational corporations, simply by their nature, are difficult to regulate: they are fictitious legal beings, the principles of separate legal personality and limited liability distance parent companies from the actions of their subsidiaries abroad, and they operate around the world subjected by infinitely different laws. ${ }^{101}$ This creates a political unwillingness to get involved, especially given that at international law states also have no enforceable obligation to regulate their corporations. ${ }^{102}$

In light of these strong influences of multinational corporations, this paper argues that the obligation to hold corporations accountable must not only fall to home and host states, but to other states where corporations hold assets.

\section{B The Ruggie Report}

\section{$1 \quad$ The Ruggie Report: A nuanced approach to balancing business and human rights}

The Ruggie Report, "Protect, Respect and Remedy: A Framework for Business and Human Rights", is the most successful step the United Nations has made towards harmonising

\footnotetext{
${ }^{97}$ Christopher Albin-Lackey

${ }^{98}$ Chrisopher Albin Lackey

${ }^{99}$ Foley smith page 157

${ }^{100}$ Ruggie 2011, above n 6.

${ }^{101}$ Deva, Surya - pages 50-51. "Out of a number of numerous examples, a few illustrative ones should suffice to support this point. The US government has opposed the use of the ATCA to make companies accountable for human rights abuses abroad (S. Joseph, "Corporations and Transnational Human Rights Litigation" Oxford: Hart Publishing, 2004, page 55-60). Attempts to enact an extraterritorial law to regulate the overseas activities of corporations registered in their respective jurisdictions have failed in the US, Australia and the UK (see footnote 17 , page 51 of Deva)."

${ }^{102}$ United Nations High Commissioner on Human Rights on the responsibilities of transnational corporations and related business enterprises with regard to human rights
} 
economic globalisation and human rights. ${ }^{103}$ Previous initiatives were largely controversial or ineffective as they either imposed wide-reaching legal duties on corporations or made the regulation scheme voluntary. ${ }^{104}$ The Ruggie Report instead focuses on the existing human rights regime binding on States at international law ${ }^{105}$ adapting it "to provide more effective protection to individuals and communities against corporate related human rights harm."

In 2011 the Ruggie Report produced the Guiding Principles on Business and Human Rights (Guiding Principles) to implement the framework. ${ }^{107}$ These Guiding Principles rest on three pillars: ${ }^{108}$

1. The State duty to protect against human rights abuses by third parties;

2. The corporate responsibility to respect human rights; and,

3. The need for more effective access to remedies.

These Guiding Principles entail the legal obligation on states to protect and promote human rights against third parties, including corporations. This is consistent with the Ruggie Report approach to avoid attributing too much liability to corporations as it is noted that: ${ }^{109}$

\footnotetext{
103 John H. Knox "The Human Rights Council Endorses "Guiding Principles" for Corporations" Vol 15, Issue 21 American Society of International Law Insights (1 August 2011) $<$ http://www.asil.org/pdfs/insights/insight110801.pdf $>$; Larry Catá Backer "From Moral Obligation to International Law: Disclosure Systems, Markets and the Regulation of Multinational Corporations" (2007-2008) 39 Geo. J. Int'1 L. 591; Faith Stevelman "Global Finance, Multinationals and Human Rights: With Commentary on Backer's Critique of the 2008 Report by John Ruggie" (2011) 9 Santa Clara J. Int'1 L. 101; Scott Jerbi "Business and Human Rights at the UN: What Might Happen Next?" (May 2009) 31 Human Rights Quarterly 299.

104 1970s-1980s: Draft Code of Conduct for Transnational Corporations (so contentious it was abandoned); 1999: the Global Compact (achieved wide consensus, however was a voluntary initiative thus had very limited effectiveness); 2003: Draft Norms on the Responsibilities of Transnational Corporations and Other Business Enterprises with Regard to Human Rights (very controversial as attempted to impose legally binding obligations on corporations to protect human rights. The initiative was therefore not adopted by the Human Rights Commission at the time.)

${ }^{105}$ Malcolm D. Evans International Law (3rd ed, Oxford University Press, New York, 2010) at 794 - 795: The Human Rights Regime consists of the Universal Declaration of Human Rights, the International Convention of Civil and Political Rights, the International Covenant on Economic, Social and Cultural Rights, the Convention on the Rights of the Child, the Convention on the Elimination of All Forms of Discrimination Against Women, the International Convention on the Elimination of All Forms of Racial Discrimination, the Convention against Torture and Other Cruel, Inhuman or Degrading Treatment or Punishment and others; see also, Eric A. Posner The Perils of Global Legalism (The University of Chicago, Chicago, 2009), at 182 - 183.

${ }^{106}$ Ruggie 2008, above $\mathrm{n} 7$ at 189.

${ }^{107}$ Ruggie 2011, above n 6 at 6.

108 Ibid.

109 John H Knox “The Human Rights Council Endorses 'Guiding Principles' for Corporations" American Society of International Law Insights (1 August 2011) <www.asil.org >.
} 
while corporations may be considered "organs of society" they are specialized economic organs, not democratic public interest institutions. As such, their responsibilities cannot and should not simply mirror the duties of States.

The Ruggie Report does not propose that States are responsible for the actions of third parties or any human rights abuse caused by them. ${ }^{110}$ Instead, it is proposed that States can be held liable where they "fail to take appropriate steps to prevent, investigate, punish and redress private actors' abuse."111 As explained in more detail below, these failures include raising barriers that could lead to a denial of access to remedy. In light of this and the following discussion, it is argued that the decision of the Canadian court in Yaiguaje failed to uphold their international duty to promote and protect against human rights abuse from third parties.

\section{Reflecting Ruggie in the Common Law Doctrine of Foreign Judgment Enforcement}

The Guiding Principles require a diverse range of legal and political mechanisms on regional, national and international levels in order to achieve the goal of effective regulation of corporations to promote and protect human rights. ${ }^{112}$ It is advanced here that the common law doctrine of foreign judgment enforcement can be used as one effective tool by States as a means to achieve this goal.

(a) Reflecting Ruggie

The Ruggie Report requires that the State protect against human rights abuses by third parties and offers effective access to remedies. ${ }^{113}$ The doctrine of foreign judgment enforcement, as a procedure of a domestic court, is well placed to fulfil this requirement.

As explained in the above in Part II, multinational corporations are difficult to regulate: they are economically powerful, mobile and hold great influence over host and home states. Currently, the only legally binding mechanisms regulating them are the domestic laws of

\footnotetext{
${ }^{110}$ Ruggie 2011, above n 6 at (I)(A)(1).

111 Ibid.

112 Ibid.

113 Ibid.
} 
states through constitutions and legislation. As Posner argues below, domestic courts are much more effective in regulating these enterprises than international tribunals: ${ }^{114}$

Law cannot solve problems without institutional support. Normally, such institutional support is called government. If a world government is unavailable, then the type of law that we can expect to prevail on the international stage will have to be weak, limited, malleable and vulnerable... courts can call on the coercive machinery of the executive to enforce judgments, and they can rely on funds from the legislature to keep them going.

The same argument applies to international arbitration tribunals, a common forum for international dispute resolution, as the disputing parties must consent to the jurisdiction of the arbitration and they need not always comply with the judgment. ${ }^{115}$ Often these arbitration tribunals are more commercially focussed and do not consider the impact of any action upon human rights in any detail. ${ }^{116}$

The Ruggie Report further maintains that States have the duty to: ${ }^{17}$

Protect and promote the rule of law, including by taking measures to ensure equality before the law, fairness in its application, and by providing for adequate accountability, legal certainty, and procedural and legal transparency.

By virtue of being solely administered through domestic courts, the doctrine of foreign judgment enforcement also provides an impartial forum capable of balancing the interests of human rights victims against those of the defendant corporation. These considerations will mostly be made where the Court adjudicates the merits of the defences raised against the foreign judgment in question. This step in the proceedings is discussed further in Part III below.

Overall, the difficult task of regulating multinational corporations is often best suited for a domestic court with domestic remedies. The issue is, how can the doctrine of foreign judgment enforcement develop to reflect the Ruggie Report and better implement its requirements?

(b) Expanding the doctrine of foreign judgment enforcement

As society moves the law needs to develop so that it can continue to serve the community.

\footnotetext{
${ }^{114}$ Eric A. Posner The Perils of Global Legalism (The University og Chicago, Chicago, 2009), at 128.

${ }^{115}$ Ibid, at 133.

${ }^{116}$ Ruggie 2008, above $\mathrm{n} 7$ at 196.

${ }^{117}$ Ruggie 2011, above n 6 at (I)(A)(1).
} 
[The law] is not an end in itself. Its justification exists in its capacity to serve the community and meet the function which society has ascribed to it... "The conception of law as a means to social ends and not as an end in itself; so that any part needs constantly to be examined for its purpose, and for its effect, and to be judged in the light of both and of their relation to each other." It followed that, as society is in a flux, "and in a flux typically faster than the law", the probability always exists that the law needs re-examination to determine how far it fits the society it purports to serve. ${ }^{118}$

The common law doctrine of foreign judgment enforcement is a clear example of a law that needs to be updated to reflect the current needs and values of today's society. ${ }^{119}$ The doctrine developed in the early part of the $19^{\text {th }}$ century and has not changed since. ${ }^{120}$ The Supreme Court of Canada recently called for a re-examination of the doctrine in Morguard Investments Ltd v De Savoye stating that private international law is "grounded in the need in modern times to facilitate the flow of wealth, skills and people across state lines in a fair and orderly manner." 121 In that case the Court held that the doctrine should be updated to also apply to non-money judgments in certain circumstances, reflecting the requirements of modern society.

The same may be argued about the modern requirements to protect human rights from corporate-related abuse. As shown in the Ruggie Report, there is an urgent need to update our legal and political mechanisms to reflect the modern challenges we face with economic globalisation.

\section{Part III}

Logically, the doctrine of foreign judgment enforcement will only effectively reflect the Ruggie Report in situations such as Aguinda, where there is a foreign judgment that needs to be enforced as a means of acquiring redress for wrongs suffered.

As explained in Part I above, these cases are becoming more common and are precisely the types of situations that the Ruggie Report aims to address. These cases are a direct result of "the governance gaps created by globalisation - between the scope and impact of economic forces and actors, and the capacity of societies to manage their adverse consequences", what

\footnotetext{
${ }^{118}$ Hon Mr Justice EW Thomas, "A Return to Principle in Judicial Reasoning and an Acclamation of Judicial Autonomy" (1993) 23 VUWLR Monograph 5 at 32, citing K Llewellyn "Jurisprudence: Realism in Theory and in Practice" (University of Chicago Press, Chicago, 1962) at 55-57.

${ }^{119}$ Pro Swing Inc. v. ELTA Golf (2004), 71 O.R. (3d) 566 [9].

${ }^{120}$ Oppong, page 262

${ }^{121}$ Ibid, 264.
} 
the Ruggie Report recognises as "the root cause of the business and human rights predicament today." 122 These cases fall between the whims of powerful corporations and the weaknesses of the regulations of human rights in host states.

Adapting the doctrine of judgment enforcement will not address all of the challenges brought by economic globalisation, but it will contribute to the overall aim of the Ruggie Report. It is not proposed here that a receiving court enforce all foreign judgments concerned with breach of human rights. What is proposed is that a receiving court must now apply the doctrine of foreign judgment enforcement in a manner that is consistent with their obligation under the Ruggie Report. Unlike the Canadian decision in Yaiguaje, a receiving court should consider the wider implications of their decision at an international level and have detailed regard for the promotion and protection of human rights.

The question is how will the courts practically apply the principles of the Ruggie Report when applying the doctrine of foreign judgment enforcement?

The answer must lie in refusing to follow the decision of the Canadian court in Yaiguaje. Where the foreign judgment satisfies the criteria described in Part I and is shown to be prima facie enforceable, the receiving court must allow the action to proceed to the next step where the judgment debtor files their defences, unlike in Yaiguaje. To refuse this would be to raise unnecessary barriers to justice, amounting to a breach of the principles in the Ruggie Report and thus of the obligation on the State to protect human rights: ${ }^{123}$

States should ensure that they do not erect barriers to prevent legitimate cases from being brought before the courts in situations where judicial recourse is an essential part of accessing remedy or alternative sources of effective remedy are unavailable.

The most appropriate place for a court to take these human rights considerations into account is at the defence stage of the proceedings. With the filing of defences, a receiving court will have slightly more scope to examine the case and take into account its procedural history and context. ${ }^{124}$ Here a receiving court may identify the case as one concerning corporate-related human rights abuse and apply the law consistently with its international obligation under the Ruggie Report - to protect human rights against third party human rights abuse and to provide an effective remedy where appropriate.

\footnotetext{
${ }^{122}$ Ruggie 2008, above $\mathrm{n} 7$ at 189.

${ }^{123}$ Ruggie 2011, above n 6.

${ }^{124}$ Goddard and McLachlan, page 61.
} 
The judgment debtor may raise the following defences claiming:

1. That the judgment was obtained by fraud;

2. That enforcement of the judgment would be contrary to the public policy; and,

3. That the judgment breaches natural justice.

None of the Commonwealth jurisdictions will enforce a foreign judgment that was obtained by fraud. ${ }^{125}$ This may be fraud on behalf of the judgment creditor or on behalf of the foreign court and can include bribing witnesses or procuring or giving forged or perjured evidence. ${ }^{126}$ The circumstances of when this defence will be allowed to stand are unsettled among the Commonwealth jurisdictions. ${ }^{127}$ The question arises as to whether there needs to be fresh evidence of fraud that was unable to be determined during the foreign trial, or not in which case the receiving court would have the ability to examine the case on the merits. ${ }^{128}$ It is settled that the defence of fraud is not raised lightly: ${ }^{129}$

\footnotetext{
It is not enough for a person against whom a judgment is sought to be enforced to simply allege fraud in order for the court to inquire into it: there must be full particulars and plausible evidence disclosing at least a prima facie case, to prevent summary judgment being entered or the defence being struck down as frivolous and vexatious.
}

As this defence is very factually based, it is difficult to speculate how best to generally uphold the principles of the Ruggie Report here. The Ruggie Report requires that in awarding any remedy a court must ensure that "the provision of justice is not prevented by corruption of the judicial process, that courts are independent of economic or political pressures". This would be a relevant consideration for a receiving court to make when evaluating the evidence in considering the defence of fraud. A receiving court would need to be careful to balance the interests of both the judgment debtor and the judgment creditor.

The second defence that the enforcement of the foreign judgment would be contrary to public policy is a very narrow defence. In New Zealand, this defence would only apply where the foreign judgment would "shock the conscience of a reasonable New Zealander, be contrary to

\footnotetext{
${ }^{125}$ Dicey, above n 25 at $\mathrm{r} 43$.

${ }^{126}$ Gordhan v Kerdemelidis HC Christchurch CIV-2010-409-2982, 20 December 2011 at [31].

${ }^{127}$ Goddard and McLachlan, 62.

${ }^{128}$ Goddard and McLachlan, 62.

${ }^{129}$ Goddard and McLachlan, 64. Citing Owens Bank Ltd v Etoile Commerciale SA [1995] 1 WLR 44 (PC).
} 
New Zealand's view of basic morality or a violation of essential principles of justice or moral interests" in New Zealand. ${ }^{130}$

A receiving court faced with this defence will have more scope to consider public policy including the extent of the abuse of human rights and the context in which the foreign judgment was decided.

The final defence of natural justice is a very limited defence. It is concerned with the more procedural aspects of the trial, as to whether the judgment debtor received sufficient notice to be capable of defending themselves in the proceedings. ${ }^{131}$

The receiving court should take into consideration less obvious barriers facing parties such as the frequent barriers facing parties such as financial resources, access to information and expertise. Further, where parties are from different cultural backgrounds, it is important to take into consideration the nature of the proceedings and how those might affect the ability of the parties to represent themselves. The court may keep in mind that many groups that are vulnerable to marginalisation may face "additional cultural, social, physical and financial impediments to accessing, using and benefitting from these mechanisms." ${ }^{132}$ In this case the receiving court should pay particular attention to the needs of these groups at different stages of the remedial process.

\section{Conclusion}

The Canadian Court in Yaiguaje took an unprincipled approach to the law, ultimately basing their verdict on practical matters and consequently failing to determine the case on its merits. The Court failed to respect the fundamental common law doctrines of comity and obligation and more importantly failed to consider the wider policy implications that the decision had on corporate human rights abuse. It has been shown that the common law doctrine of foreign judgment enforcement can be used as one effective tool by States to protect human rights from abuse by third parties by upholding some of the key principles outlined in the Ruggie Report.

\footnotetext{
${ }^{130}$ Goddard and McLachlan, 64 referring to Reeves v OneWorld Challenge [2006] 2 NZLR 184 at [67].

${ }^{131}$ Goddard and McLachlan, page 65.

${ }^{132}$ Ruggie 2011, above n 6 at (III)(B)(26).
} 
States must lead the way for the struggle against human rights abuse, but it requires all areas of society to ultimately achieve the goal of the Ruggie Report, as it notes: ${ }^{133}$

There is no single silver bullet solution to the institutional misalignments in the business and human rights domain. Instead, all social actors - States, businesses, and civil society - must learn to do many things differently. But those things must cohere and become cumulative.

${ }^{133}$ Ruggie 2008, above n 7 at 190. 


\section{Bibliography}

\section{A Cases}

Abouloff v Oppenheimer (1882) 10 QBD 295 (CA).

Adams v Cape Industries plc [1990] 2 WLR 657.

Aguinda v Texaco Inc 303 F 3d 470, 480 (2nd Cir 2002).

Beals v Saldanha [2003] SCJ No 77.

Beatty v Beatty [1924] 1KB 807 (CA).

BNP Paribas (Canada) v Mécs (2002) 60 OR (3d) 205.

Carl Zeiss Stiftung v Rayner \& Keeler Lts (No 2) [1967] 1 AC 853.

Chevron Corporation v Naranjo 667 F 3d (2012, USCA, $2^{\text {nd }}$ Cir).

Dow Chemical Co v Alfaro,786 S W 2d 674 (1990).

Hilton $v$ Guyot 159 US 113 (1895).

In re Union Carbide Corp Gas Plant Disaster 634 F Supp 842, 844 (SD N 1986); aff’d 809 F 2d 195 ( $2^{\text {nd }}$ Cir 1987).

Jet Holdings Inc $v$ Patel [1990] 1 QB 335.

Morguard Investments Ltd v De Savoye (1990) CanLII 29 (SCC), [1990] 3 S.C.R. 1077, 76

DLR (4th) 256.

Owens Bank Ltd v Etoile Commerciale SA [1995] 1 WLR 44 (PC).

Pro Swing Inc v Elta Golf Inc [2006] 2 SCR 612.

Reeves v OneWorld Challenge LLC [2006] 2 NZLR 184.

Schibsby v Westenholz (1870) LR 6 QB 155.

Wiwa v Royal Dutch Petroleum Co 226 F3d 88 (2d Cir 2000).

Yaiguaje et al v Chevron Corporation (2013) ONSC 2527, CV-12-9808-00CL. 


\section{B Legislation}

$1 \quad$ Canada

Courts of Justice Act 1990.

$2 \quad$ United States

Alien Tort Claims Act 1789 (codified in 28 USC).

\section{Treaties}

Universal Declaration of Human Rights

International Convention of Civil and Political Rights

International Covenant on Economic, Social and Cultural Rights

Convention on the Rights of the Child, the Convention on the Elimination of All Forms of Discrimination against Women

International Convention on the Elimination of All Forms of Racial Discrimination

Convention against Torture and Other Cruel, Inhuman or Degrading Treatment or Punishment

\section{Books and Essays in edited books}

Francisco Cabrillo and Sean Fitzpatrick The Economics of Courts and Litigation (Edward Elgar, Cheltenham, 2008).

Enzo Cannizzaro and Beatrice I Bonafé "Of Rights and Remedies: Sovereign Immunity and Fundamental Human Rights" in Ulrich Fastenrath, Rudolf Geiger, Daniel-Erasmus Khan, Andreas Paulus, Sabine von Schorlemer and Christoph Vedder (eds) From Bilateralism to 
Community Interest: Essays in Honour of Judge Bruno Simma (Oxford University Press, New York, 2011) 825.

John H. Currie, Craig Forcese and Valerie Oosterveld International Law: Doctrine, Practice, and Theory (Irwin Law, Toronto, 2007).

Surya Deva Regulating Corporate Human Rights Violations: Humanizing Business (Routledge, Abingdon, 2012).

Albert Venn Dicey, Lawrence Collins and J. H. C. Morris Dicey, Morris and Collins on the Conflict of Laws, above n 22, at 636.

Malcolm D Evans International Law (3rd ed, Oxford University Press, New York, 2010).

Peter Hipold "From Humanitarian Intervention to Responsibility to Protect: Making Utopia True?" in Ulrich Fastenrath, Rudolf Geiger, Daniel-Erasmus Khan, Andreas Paulus, Sabine von Schorlemer and Christoph Vedder (eds) From Bilateralism to Community Interest: Essays in Honour of Judge Bruno Simma (Oxford University Press, New York, 2011).

Michael Likosky Transnational Legal Processes: Globalisation and Power Disparities (Butterworths LexisNexis, London, 2002).

Radu Mares The Dynamics of Corporate Social Responsibilities (Martinus Nijhoff Publishers, Leiden, 2008).

Andrea Paulus "Reciprocity Revisited" in Ulrich Fastenrath, Rudolf Geiger, Daniel-Erasmus Khan, Andreas Paulus, Sabine von Schorlemer and Christoph Vedder (eds) From Bilateralism to Community Interest: Essays in Honour of Judge Bruno Simma (Oxford University Press, New York, 2011). 
Anne Peters "The Responsibility to Protect: Spelling out the Hard Legal Consequences for the UN Security Council and its Members" in Ulrich Fastenrath, Rudolf Geiger, DanielErasmus Khan, Andreas Paulus, Sabine von Schorlemer and Christoph Vedder (eds) From Bilateralism to Community Interest: Essays in Honour of Judge Bruno Simma (Oxford University Press, New York, 2011).

Stephen Pitel and Nicholas Rafferty Conflict of Laws (Irwin Law, Toronto, 2010).

Pemmaraju Sreenivasa Rao “The Concept of 'International Community' in International Law and the Developing Countries" in Ulrich Fastenrath, Rudolf Geiger, Daniel-Erasmus Khan, Andreas Paulus, Sabine von Schorlemer and Christoph Vedder (eds) From Bilateralism to Community Interest: Essays in Honour of Judge Bruno Simma (Oxford University Press, New York, 2011).

David Sloss "Treaty Enforcement in Domestic Courts: A Comparative Analysis" in David Sloss (ed) The Role of Domestic Courts in Treaty Enforcement: A Comparative Study (Cambridge University Press, New York, 2009).

EW Thomas A Return to Principle in Judicial Reasoning and an Acclamation of Judicial Autonomy (Victoria University of Wellington Law Review, Palmerston North, 1993).

Stephen Tully Corporations and International Lawmaking (Martinus Níjhoff Publishers, Massachusetts, 2007).

Michael P Van Alstine "The Role of Domestic Courts in Treaty Enforcement: Summary and Conclusions" in David Sloss (ed) The Role of Domestic Courts in Treaty Enforcement: A Comparative Study (Cambridge University Press, New York, 2009). 
Barbara K Woodward Global Civil Society in International Lawmaking and Global

Governance: Theory and Practice (Martinus Nijhoff Publishers, Leiden, 2010).

\section{E Journal Articles}

Larry Catá Backer "From Moral Obligation to International Law: Disclosure Systems, Markets and the Regulation of Multinational Corporations" (2008) 39 Geo J Int'l L 591.

Marussia Borm-Reid "Recognition and Enforcement of Foreign Judgments" (1954) 3 International and Comparative Law Quarterly 49.

E.E. Daschbach "Where there is a will there is a way: the cause for a cure and remedial prescriptions for Forum non conveniens as applied in Latin American Plaintiff's Actions against US multinationals” 13 L. \& Bus. Rev. Am. 11, 24 (2007).

Lucien J Dhooge “Aguinda v ChevronTexaco: Mandatory Grounds for the Non-Recognition of Foreign Judgments for Environmental Injury in the United States (2010) 19 J Transnat'l L Pol'y 1.

Lloyd Doggett "Forum Non Conveniens, United States Multinational Corporations, and Personal Injuries in the Third World: Your Place or Mine?" (1991) 11 BC Third World LJ 249.

Rosemary H Do "Not Here, Not There, Not Anywhere: Rethinking the Enforceability of Foreign Judgments with Respect to the Restatement (Third) of Foreign Relations and the Uniform Money-Judgments Recognition Act of 1962 in Light of Nicaragua's DBCP Litigation” (2008) 14 Sw J L \& Trade Ame 409.

Steven R Donzinger "Rainforest Cherbonyl: Litigating Indigenous Rights and the Environment in Latin America" (2004) Hum Rts Brief. 
Celia Wasserstein Fassberg "Rule and Reason in the Common Law Foreign Judgments" (1999) 12 Can J L \& Jurisprudence 193.

Dante Figueroa "Conflicts of Jurisdiction Between the United States and Latin America in the Context of Forum Non Conveniens Dismissals" (2006) 37 Miami Inter-American Law Review 199.

Nicholas A Fromherz “A Call For Stricter Appellate Review of Decisions on Forum Non Conveniens" (2012) 11 Washington University Global Studies Law Review 527.

Walter W Heiser "Forum Non Conveniens and Retaliatory Legislation: The Impact on the Available Alternative Forum Inquiry and on the Desireability of Forum Non Conveniens as a Defense Tactic” (2009) 56 Kansas Law Review 609.

Scott Jerbi "Business and Human Rights at the UN: What Might Happen Next?" (2009) 31 Human Rights Quarterly 299.

Judith Kimberling "Oil, contact and conservation in the Amazon: Indigenous Huaroni, Chevron and Yasuni” (2013) 24 Colo J Int'l Envtl L \& Pol'y 43.

Matthew Lippman "Transnational Corporations and Repressive Regimes: The Ethical Dilemma" (1985) 14 Cal W Int'1 LJ 542.

Michael T Manzi "Dow Chemical Company v Castro Alfaro: The Demise of Forum Non Conveniens in Texas and One Less Barrier to International Tort Litigation" (1990) 14 Fordham International Law Journal 819.

PT Muchlinski "Holding Multinationals to Account: Recent Developments In English Litigation And The Company Law Review I" (2002) Amicus Curiae 39. 
Richard Frimpong Oppong "Enforcing Foreign Non-Money Judgments: An Examination of Some Recent Developments in Canada and Beyond” (2006) 30 UBC L Rev 257.

Suraj Patel "Delayed Justice: A Case Study of Texaco and the Republic of Ecuador's Operations, Harms and Possible Redress in the Ecuadorian Amazon" (2012) 26 Tul Envtl L J 71.

Joel R Paul "The Transformation of International Comity" (2008) 71 Law \& Comtemp Probs 19.

Kim Pham "Enforcement of Non-Monetary Foreign Judgments in Australia" (2008) 30 Sydney L Rev 663.

Erin Foley Smith "Right to Remedies and the Inconvenience of Forum non Convenienes: Opening US Courts to Victims of Corporate Human Rights Abuses" (2011) 44 Colum JL \& Soc Probs 145.

Erwin Spiro "The incidence of Jurisdiction in the Recognition and Enforcement of Foreign Judgments" (1978) Acta Juridica 59.

Faith Stevelman "Global Finance, Multinationals and Human Rights: With Commentary on Backer's Critique of the 2008 Report by John Ruggie” (2011) 9 Santa Clara J Int'1 L 101.

William E Thomson and Perlette Michele Jura "Unconstitutional Judgments for Import: Constitutional Limitations on Recognition and Enforcement of Abusive Foreign Judgments" (2011) Pepperdine Law Review Online 43.

Christopher Whytock "Forum Non Conveniens and the Enforcement of Foreign Judgments" (2011) 111 Columbia Law Review 1444. 


\section{F Reports}

Office of the United Nations High Commissioner for Human Rights "Report of the Office of the High Commissioner for Human Rights on the responsibilities of transnational corporations and related business enterprises" E/CN 4/2005/91 (2005).

John Ruggie "Report of the Special Representative of the Secretary-General on the issue of human rights and transnational corporations and other business enterprises" A/HRC/17/31 (2011).

John Ruggie "Report of the Special Representative of the Secretary-General on the Issue of Human Rights and Transnational Corporations and Other Business Enterprises: Protect, Respect and remedy: A Framework for Business and Human Rights, delivered to the Human Rights Council” UN Doc A/HR/8/5 (Apr 7 2008).

\section{G Internet resources}

Ralf Michaels "Recognition and Enforcement of Foreign Judgments" (2009) Max Planck Institute for Comparative Public and International Law, Heidelberg and Oxford University Press <www.mpepil.com>.

William Langewiesche "Jungle Law” (May 2007) Vanity Fair <www.vanityfair.com>. 
Christopher Albin-Lackey "Without Rules: A Failed Approach to Corporate Accountability" (January 2013) Human Rights Watch <www.globalpolicy.org>.

Global Trends "Corporate Clout 2013: Time for Responsible Capitalism" (2004) $<$ www.globaltrends.com $>$.

Sasha Lilley "Barren Justice” (2004) CorpWatch <www.corpwatch.org $>$.

John H Knox "The Human Rights Council Endorses 'Guiding Principles' for Corporations" American Society of International Law Insights (1 August 2011) <www.asil.org >.

Julian Ku and George Conway "When Corporate Defendants Go on Offense; How an \$18 billion judgment against Chevron in Ecuador turned into a battle royal with a top U.S. law firm" Wall Street Journal (Online) (4 July 2013).

\section{H Other resources}

David Goddard and Campbell McLachlan "Private International Law - litigating in the trans-Tasman context and beyond" (seminar presented to the New Zealand Law Society, Wellington, August 2012).

Simon Romero and Clifford Krauss "A Well of Resentment" The New York Times (United States, 15 May 2009) at B1. 